\title{
Os desafios a uma Política Nacional de Desenvolvimento Regional no Brasil*
}

\author{
Paulo Pitanga do Amparo** \\ (Paulo.Amparo@integracao.gov.br)
}

Recebido em 22/02/2013; revisado e aprovado em 15/04/2013; aceito em 10/08/2013

É com muita honra e satisfação que represento o professor Sérgio Castro, Secretário da Secretaria de Desenvolvimento Regional do Ministério da Integração Nacional, nesta palestra do I Seminário Internacional sobre Desenvolvimento Territorial Sustentável, organizado pelo Mestrado Acadêmico em Desenvolvimento Local da Universidade Católica Dom Bosco (UCDB) de Campo Grande, MS, em parceria com o Programa Internacional Master Erasmus Mundus da Comissão Europeia.

Antes de iniciar, gostaria igualmente de saudar aos integrantes da mesa, na pessoa dos professores Hemerson Pistori, Pró-reitor de Pesquisa e Pós-graduação desta Universidade, e Cleonice Le Bourlegat, Diretora Acadêmica do Programa Erasmus Mundus na UCDB, bem como aos professores, pesquisadores, alunos e representantes de instituições e organizações de governo e da sociedade civil aqui presentes.

O palestrante que me antecedeu, o prof. Pierpaolo Faggi, da Universidade de Pádua, nos brindou com um instigante estudo de caso: os dilemas de sustentabilidade que enfrenta o Sahel, região às bordas do deserto do Sahara, que passa recorrentemente por períodos de secas severas, cujos impactos têm provocado desastres sociais e grandes prejuízos econômicos, colocando, recorrentemente, a segurança hídrica e alimentar de mais de 50 milhões de pessoas de diversos países situados naquela faixa de terra do continente africano em situação extremamente delicada.

Pois bem, eu os convido agora a deixarmos as planícies do Sahel em rumo do Planalto Central do Brasil, mais precisamente para Brasília, sede do Governo Federal, para examinar os desafios que enfrentam os gestores públicos para planejar e executar políticas nacionais voltadas à diminuição das desigualdades regionais do país. Como sabemos, essas diferenças socioeconômicas entre regiões são graves e historicamente persistentes. Sobre este assunto, examinemos então o Cartograma I.

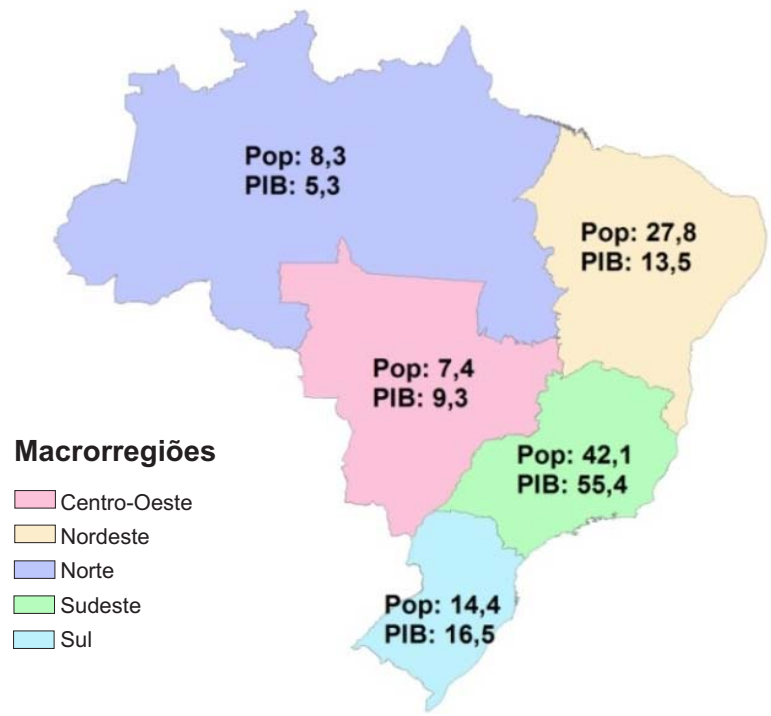

Cartograma I - Participação por Região no total da População e do PIB Brasileiro (\%) 2010

Elaboração: CGMA/SDR/MI

(Fonte Censo 2010)

\footnotetext{
* Agradeço as valiosas contribuições do Professor Doutor Carlos Wagner, do IPEA, em especial suas oportunas observações referentes à análise econômica da primeira parte deste texto; ao Professor Doutor Jacques Salomon, pelas sugestões de normalização técnica; e à colega Laís Cordeiro, deste Ministério da Integração Nacional.

** Coordenador Geral de Planejamento Estratégico da Secretaria de Desenvolvimento Regional do Ministério da Integração Nacional, Brasília, DF, Brasil. Doutor (1995) em Políticas Públicas e Meio Ambiente pela Heriot-Watt University (School of Town and Country Planning/ Edimburgo - Escócia, Reino Unido).
} 
Salta logo à vista a elevada participação, em 2010, do Sudeste no total do Produto Interno Bruto (PIB) do Brasil: 55,4\%. Como a produção de bens e serviços tem uma contrapartida na geração da renda, já que fatores de produção (terra, capital e trabalho) são utilizados no processo produtivo, pode-se dizer, grosso $\operatorname{modo}^{1}$, que naquela região, naquele ano, foram gerados mais da metade dos salários, lucros, juros, dividendos, aluguéis, etc. do país. Essa concentração de renda, sem dúvida, tem se atenuado - discretamente - ao longo das últimas décadas, pois, em 1970, a participação do PIB do Sudeste no PIB do Brasil chegava a $65,1 \%$.

Ainda com base no Cartograma I, é possível perceber outro aspecto da concentração regional se comparamos o PIB com a população (Pop) das macrorregiões brasileiras. Notem que a razão PIB/Pop das três macrorregiões do Centro-sul do país (Sul, Sudeste e Centro-Oeste) é superior a 1, enquanto no Norte e Nordeste essa relação se inverte, indicando que o valor monetário dos bens e serviços (finais) produzidos naquelas três regiões é proporcionalmente superior à sua população, contrastando com a situação no Norte e Nordeste, onde a mesma razão é extremamente baixa $(0,64$ para o Norte e 0,49 para o Nordeste, contra 1,14 no Sul, 1,26 no Centro-Oeste e 1,32 no Sudeste). Dessas evidências, é possível afirmar que, em 2010, cada habitante das regiões Sul, Centro-Oeste e Sudeste auferiu, em média, renda - derivada, como mencionado anteriormente, da agregação de valor que ocorre ao longo do processo de produção dos três setores da economia (primário, secundário e terciário) - muito superior àquela gerada nas regiões Norte e Nordeste.

Pode-se argumentar que o olhar macrorregional não permite distinguir a concentração econômica tal como distribuída no país como um todo. Vejamos então o Cartograma II, que retrata o rendimento domiciliar médio por habitante, por município, em 2010. Esse dado, diferentemente do PIB, é gerado decenalmente, por ocasião das visitas dos recenseadores do IBGE aos, hoje, $5.570 \mathrm{mu}$ nicípios brasileiros, e indica a apropriação pelas famílias da renda gerada no processo produtivo, em dado ano.

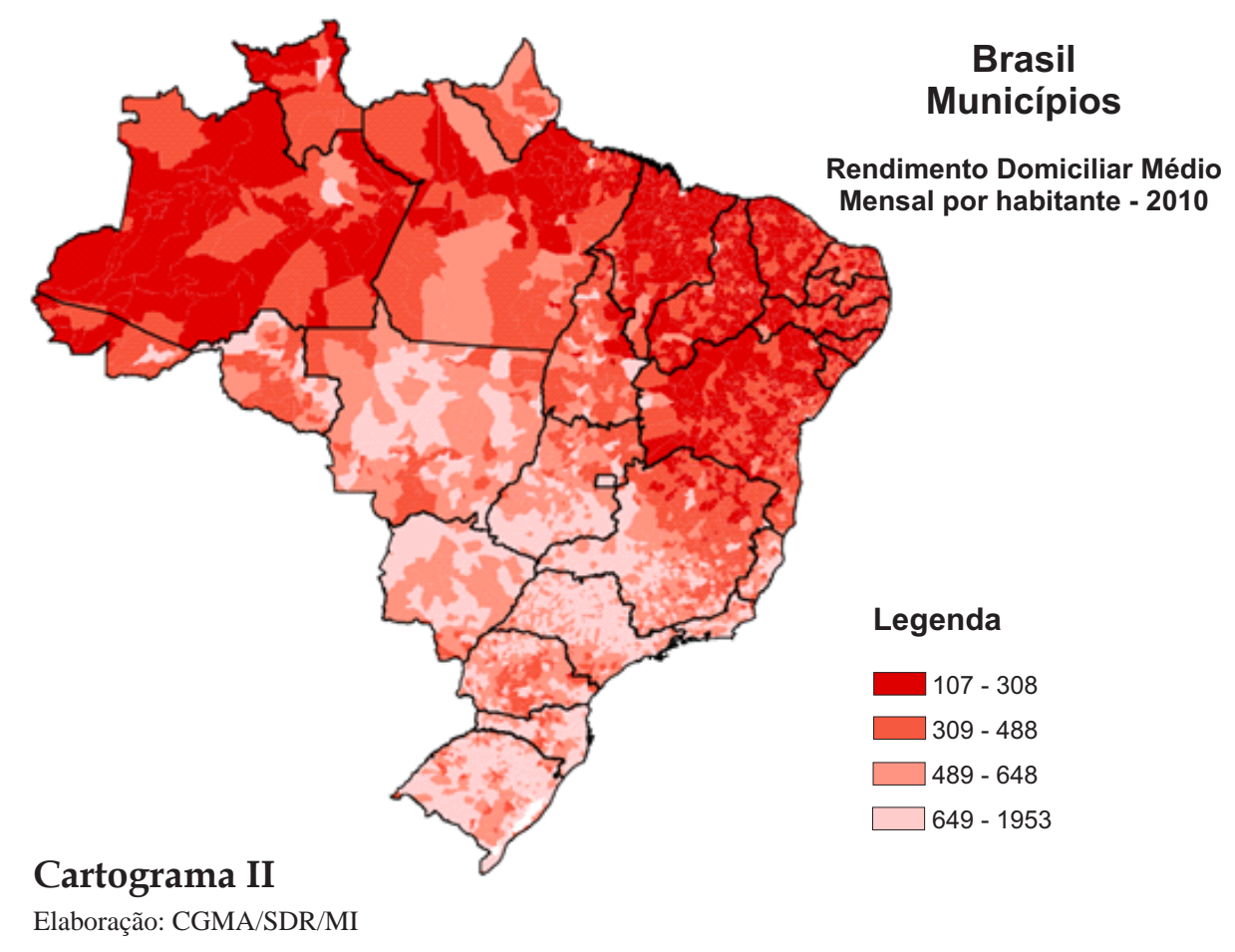

\footnotetext{
1"Grosso modo" porque regionalmente - macrorregiões, estados, municípios - podem surgir diferenças, devido às metodologias de apuração do produto e da renda pelo IBGE. Na contabilização do PIB de uma região, esse instituto não considera as remessas de recursos e os recebimentos efetuados, enquanto na medida da renda
}

$\overline{\text { são aferidos os rendimentos dos residentes daquela }}$ região, que podem ter sido obtidos em outra região. No caso da renda, as "rendas recebidas ou enviadas para outras regiões" são contabilizadas, o que não acontece com o PIB regional, daí, portanto, a possibilidade de surgirem eventuais diferenças entre ambos os agregados. 
O Cartograma II fala por si e confirma as observações feitas anteriormente. No Brasil, os municípios onde o rendimento domiciliar médio mensal é menor (em vermelho rubro $-1^{\circ}$ quartil) se situam, em sua grande maioria, nas regiões Norte e Nordeste, podendo-se incluir naquela categoria a região semiárida do norte de Minas Gerais, que faz parte, inclusive, da área de atuação da SUDENE. Municípios em situação intermediária e de maior rendimento ocorrem em todas as macrorregiões, inclusive no Nordeste e Norte (a maioria das capitais dos Estados e centros urbanos de maior porte), mas com concentração evidente no Centrosul do país.

É preciso, todavia, notar que desigualdades econômicas inter e intrarregionais não refletem apenas desníveis da capacidade produtiva das economias regionais, mas também desequilíbrios espaciais na oferta de emprego ${ }^{2}$ e na disponibilidade de serviços públicos (educação, saúde, saneamento, transportes); na expectativa de vida ao nascer; na capacidade institucional dos governos subnacionais, etc... Daí se afirmar que acentuadas desigualdades regionais não se referem apenas à capacidade produtiva de um território vis-àvis outro, mas expressam, igualmente, uma situação de iniquidade social, pois o lugar de nascimento passa a ser condição-chave de acesso a oportunidades de ascensão social e a uma vida digna.

A afirmativa acima é ilustrada nos cartogramas III, IV e V abaixo, que confirmam a correlação entre níveis de indicadores econômicos e sociais dos municípios do país, pois é possível perceber a pior condição relativa das regiões Norte e do Nordeste, comparativamente às regiões Sul, Sudeste e Centro-Oeste nos seguintes indicadores sociais selecionados: i) Qualidade da Educação, ii) Acesso a Serviços Básicos Urbanos, e iii) Atendimento dos Serviços de Saúde.

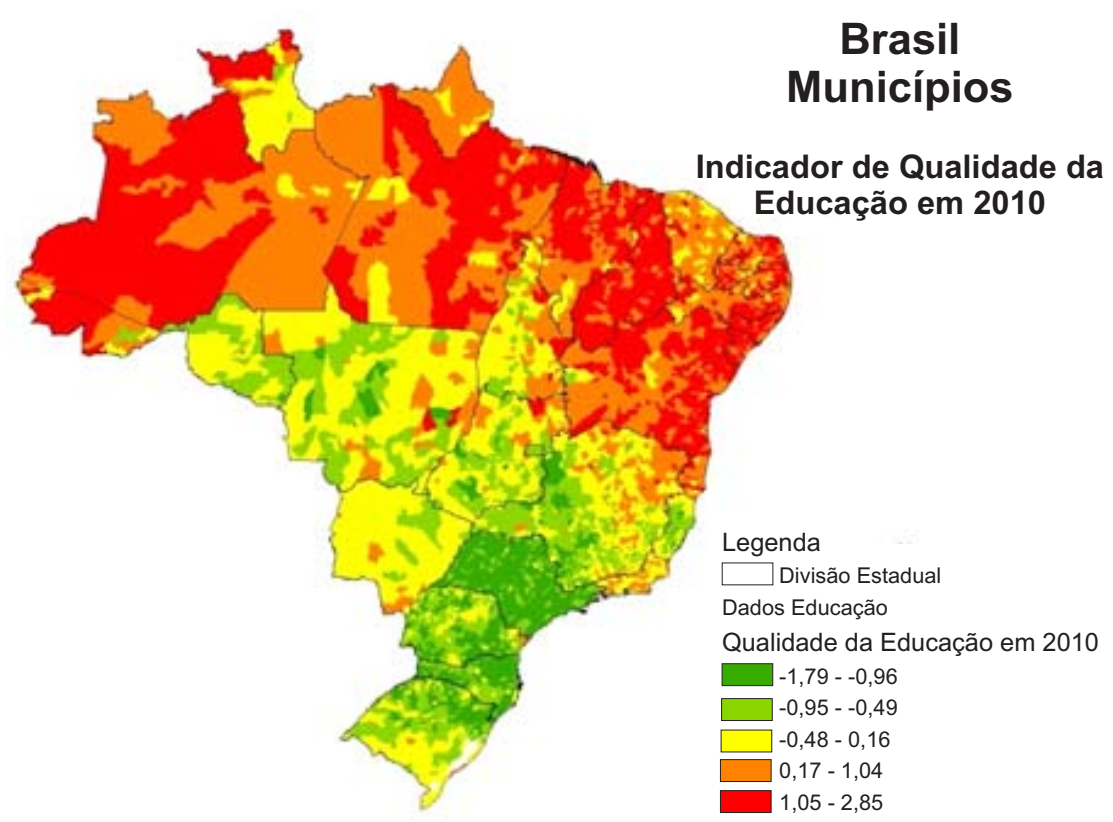

Cartograma III - Qualidade da Educação nos municípios brasileiros

Indicador elaborado pela CGMA/SDR/MI e composto dos seguintes indicadores:

- Taxa Distorção Idade Série no Ensino Fundamental (INEP 2010);

- Taxa Distorção Idade Série no Ensino Médio (INEP 2010);

- Percentual de pessoas de 15 anos ou mais analfabetas (Censo Demográfico 2010).

\footnotetext{
${ }^{2}$ As disparidades regionais da oferta de emprego e suas repercussões pelo lado da renda regional são válidas no caso brasileiro, mas cabe notar que há situações em que uma maior oferta de emprego em dada região não produz impacto correspondente na renda per capita dessa região, quando comparada a outra região, onde uma menor oferta de emprego gera renda per capita
}

$\overline{\text { maior do que primeira. Isso se dá quando a qualidade }}$ do emprego na segunda região (de renda per capita maior) é bem maior do que na anterior. Compare-se, por exemplo, os casos da China e EUA. A oferta de emprego (absoluto) na China é bem maior do que nos EUA, mas a renda per capita nos EUA é maior. 


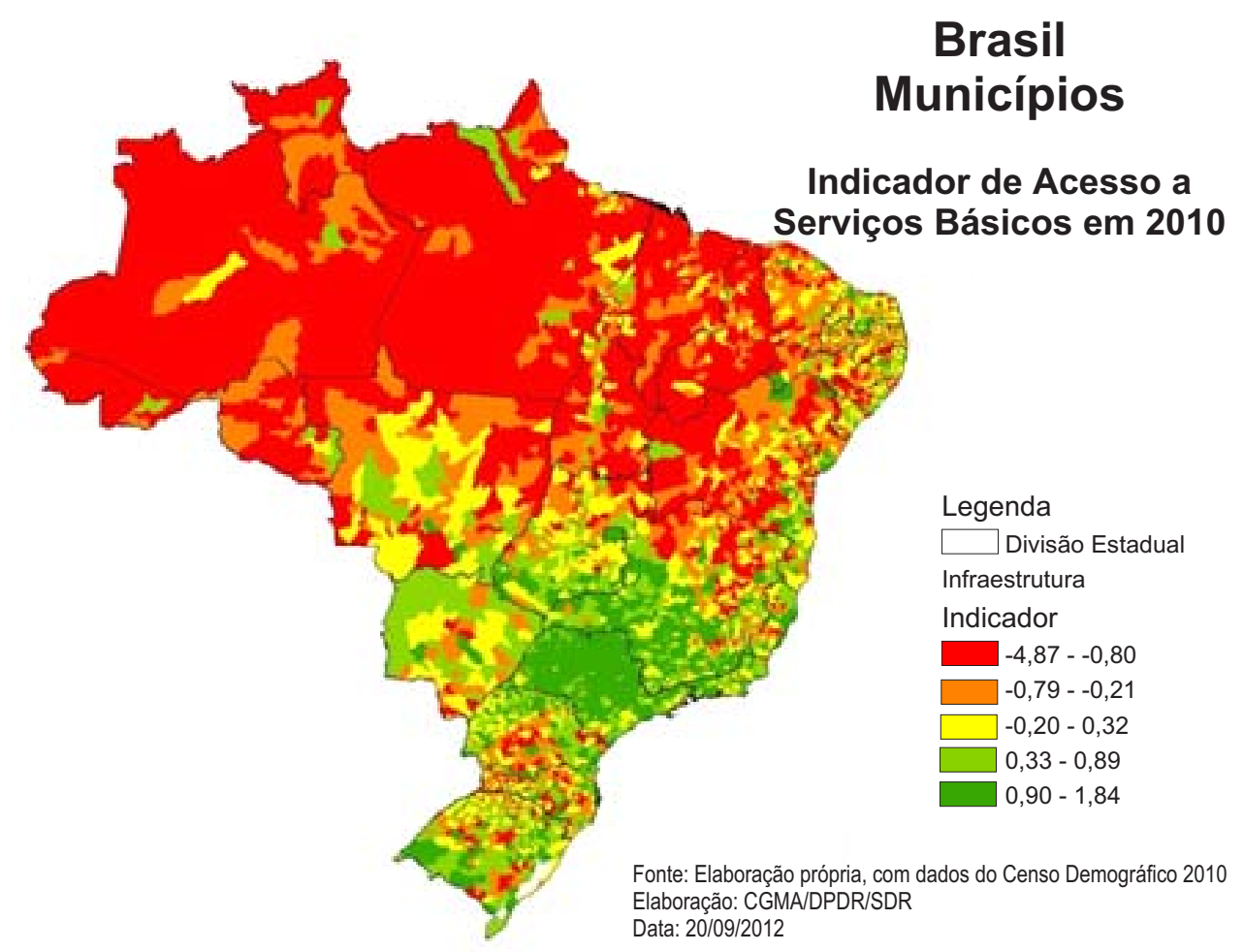

\section{Cartograma IV: Acesso a Serviços Públicos Urbanos, por município}

Indicador elaborado pela CGMA/SDR/MI e composto dos seguintes indicadores:

- Percentual de moradores em domicílios particulares com destino do lixo coletado (Censo 2010);

- Percentual de moradores em domicílios particulares com acesso à rede geral de água (Censo 2010);

- Percentual de moradores em domicílios particulares com acesso à rede coletora de esgoto (Censo 2010);

- Percentual de moradores em domicílios particulares com acesso à energia elétrica (Censo 2010).

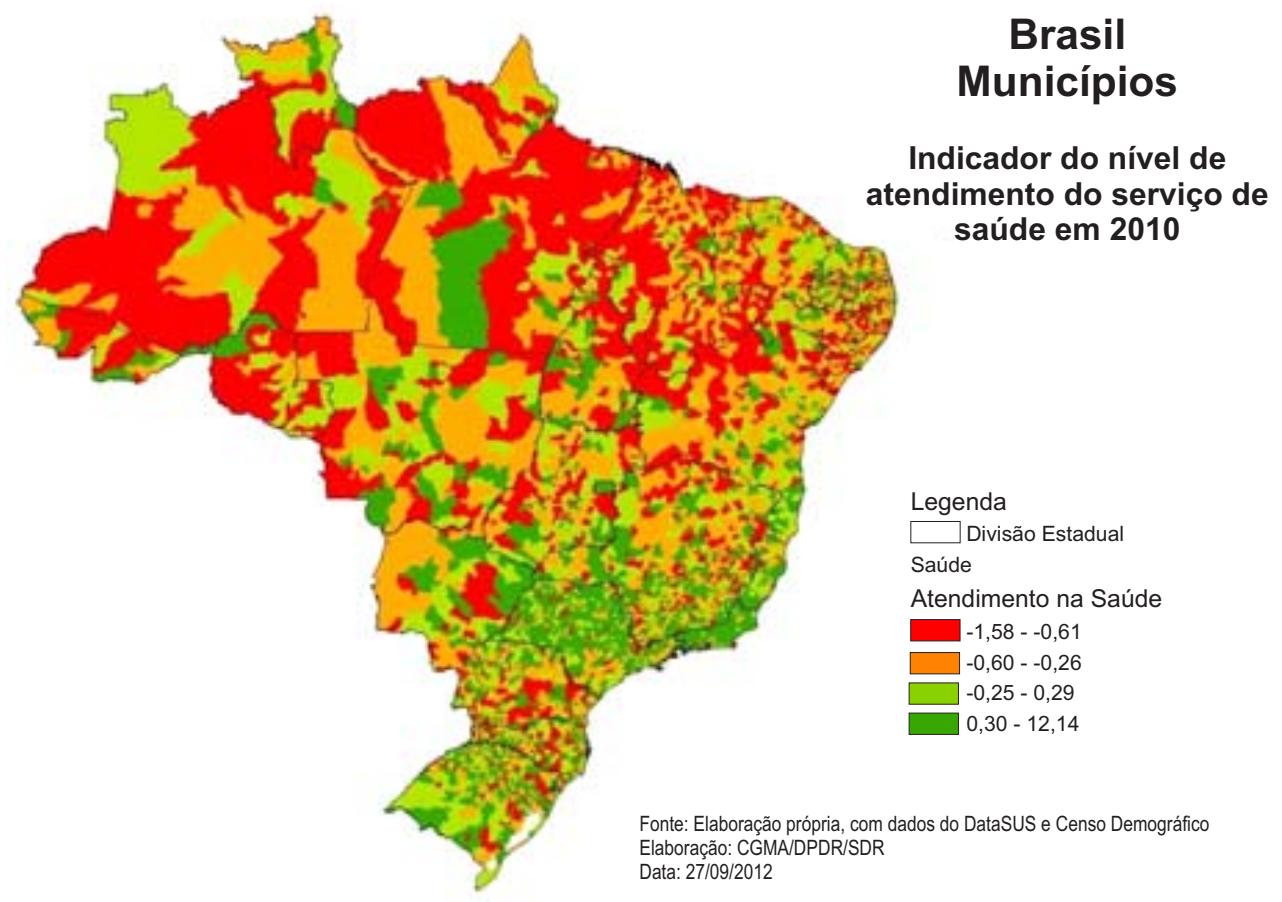

\section{Cartograma V: Nível de atendimento dos serviços de saúde}

Indicador elaborado pela CGMA/SDR/MI e composto dos seguintes indicadores:

- Número de enfermeiros por 1.000 habitantes, em 2010 (DATASUS).

- Número de médicos por 1.000 habitantes, em 2010 (DATASUS). 
Outro ângulo pelo qual é possível observar o fenômeno das desigualdades socioespaciais do país é através da distribuição de sua rede urbana. A esse respeito, notem, no Cartograma VI abaixo, a grande concentração urbana na faixa litorânea e nas regiões Sul e Sudeste do Brasil, e a fragilidade das demais regiões, reflexo do processo de ocupação produtiva do território brasileiro ao longo da formação econômica do Brasil, como nos ensina o professor Celso Furtado.

Como se sabe, as cidades são a localização preferencial da indústria de transformação e do setor de serviços, já que os agentes públicos ou privados tendem naturalmente a posicionarem-se próximo ao mercado consumidor. E os consumidores, por sua vez, buscam igualmente localizarem-se em áreas urbanas em que o acesso a bens e serviços (comércio, intermediação financeira, saúde, educação, transporte, etc...) lhes é facilitado, gerando-se assim um fluxo circular cumulativo, pelo qual uma tendência reforça a outra, fenômeno que é desafio relevante à eficácia de políticas públicas que buscam desconcentrar a atividade econômica e a ocupação populacional ao interior do país.

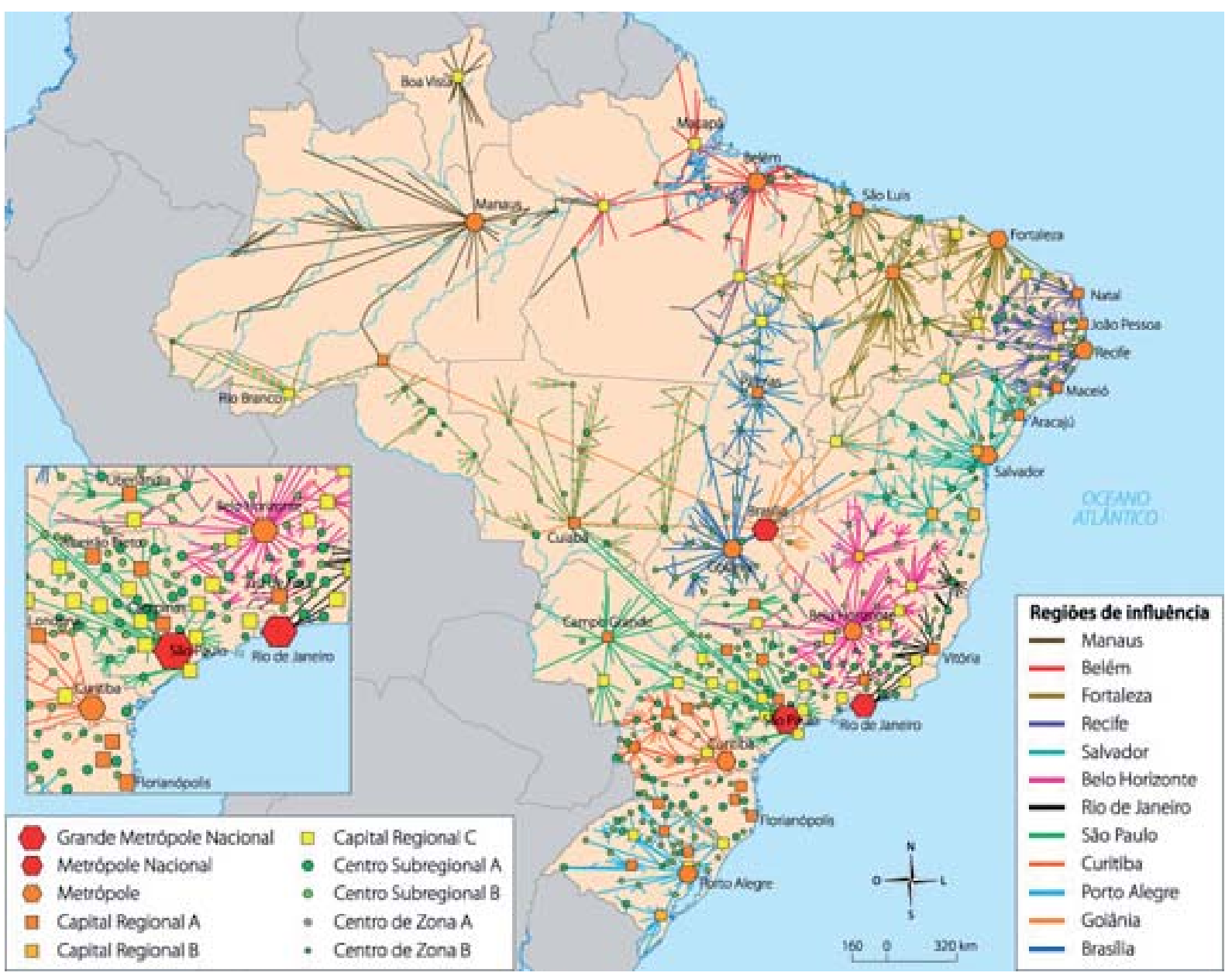

Cartograma VI - Rede Urbana, Brasil - 2007

Fonte: IBGE, Regiões de Influência das Cidades (2007) 
Um último aspecto a salientar refere-se à persistência no tempo das desigualdades regionais no Brasil, sempre pelo ângulo das grandes regiões. Notem os dois extremos (1939-2003) da série temporal do Gráfico I. Nesse período, as rendas (PIB) per capita das regiões Norte e Nordeste, relativamente à média do país, permaneceram praticamente no mesmo patamar, mesmo com algumas flutuações significativas em determinados períodos, mais acentuadas na trajetória da região Norte. A despeito dos pesados investimentos carreados ao Nordeste através dos I e II Planos Nacionais de Desenvolvimento (1972-1974/1975-1979), dos incentivos fiscais (FINOR) e dos recursos aportados pelo Fundo Constitucional de Financiamento do Nordeste (FNE), a região permanecia, em 2003, com a menor renda per capita relativa do país, com uma participação inferior a 50\% da média nacional.

Já a tendência das regiões Sul e Sudeste revela gradual convergência, no período considerado, para um patamar de $130 \%$ da média nacional. A trajetória surpreendente fica, no entanto, com a região Centro-Oeste que, por conta da criação de Brasília e da entrada do agronegócio nos cerrados, vê sua renda per capita passar, desde fins da década de 70, de algo em torno de $65 \%$ para $110 \%$ da média nacional, o que sugere a perspectiva de a região alcançar, em futuro próximo, o patamar das regiões Sul e Sudeste.

O Gráfico II é igualmente interessante porque dá zoom nas tendências acima examinadas para período mais recente (1995-2008). Note-se a continuidade do processo de convergência dos PIB per capita do Sul e Sudeste e um ligeiro arrefecimento do dinamismo do Centro-Oeste, cujo pico de expansão aconteceu em 2003. A boa notícia é o lento, mas persistente crescimento dos PIB per capita do Nordeste e Norte, por força, muito provavelmente, dos investimentos governamentais federais e dos programas sociais dos governos FHC e Lula. Infelizmente, no entanto, na hipótese - pouco provável, aliás - da manutenção do ritmo de crescimento dos PIB dessas regiões, a convergência desse indicador com os das regiões do Centro-sul se daria por volta de 2073!

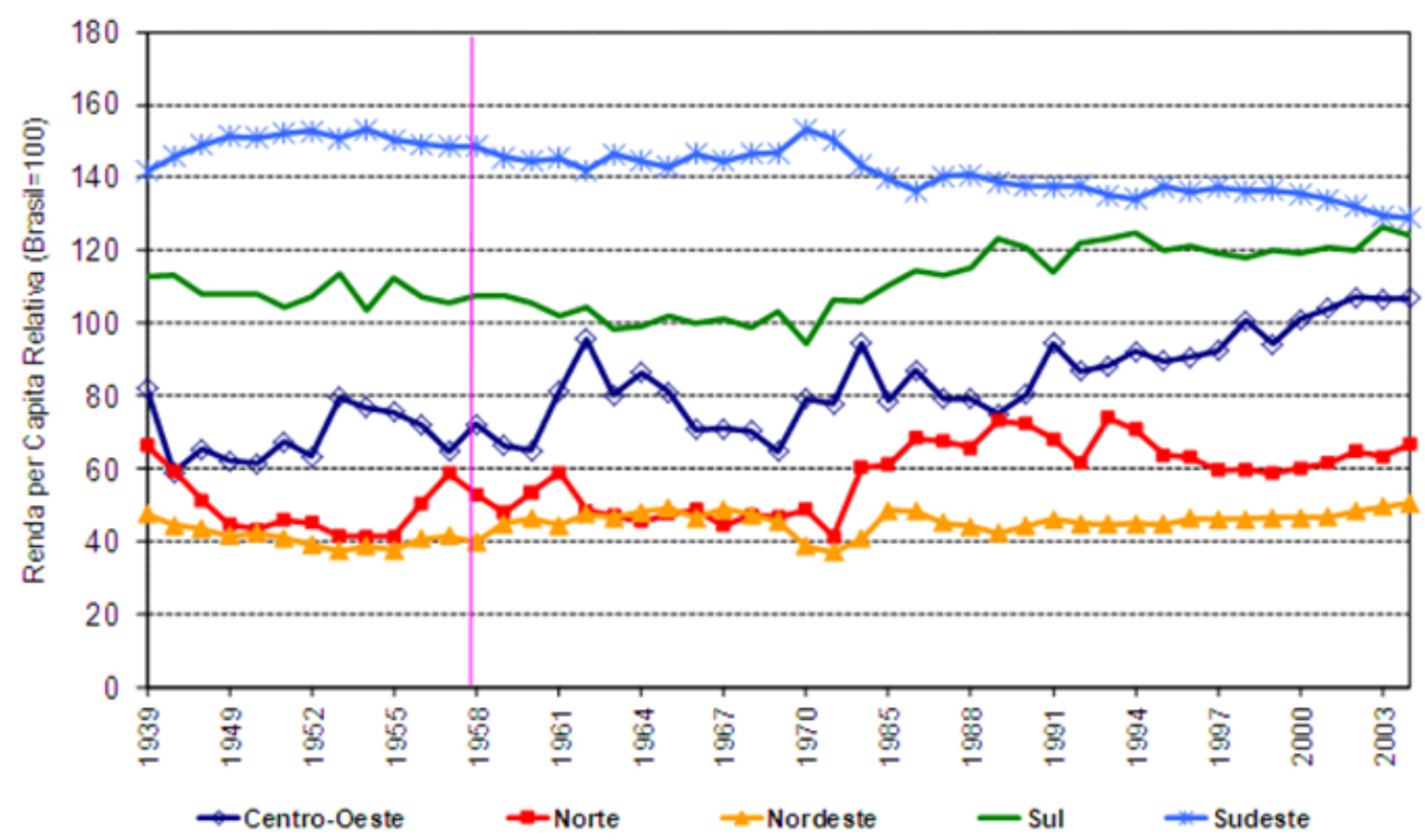

Gráfico I - Evolução (\%) da renda per capita das macrorregiões em relação à média brasileira. 


\section{Razão entre o PIB per capita das macrorregiões e o PIB per capita brasileiro (1995-2008)}

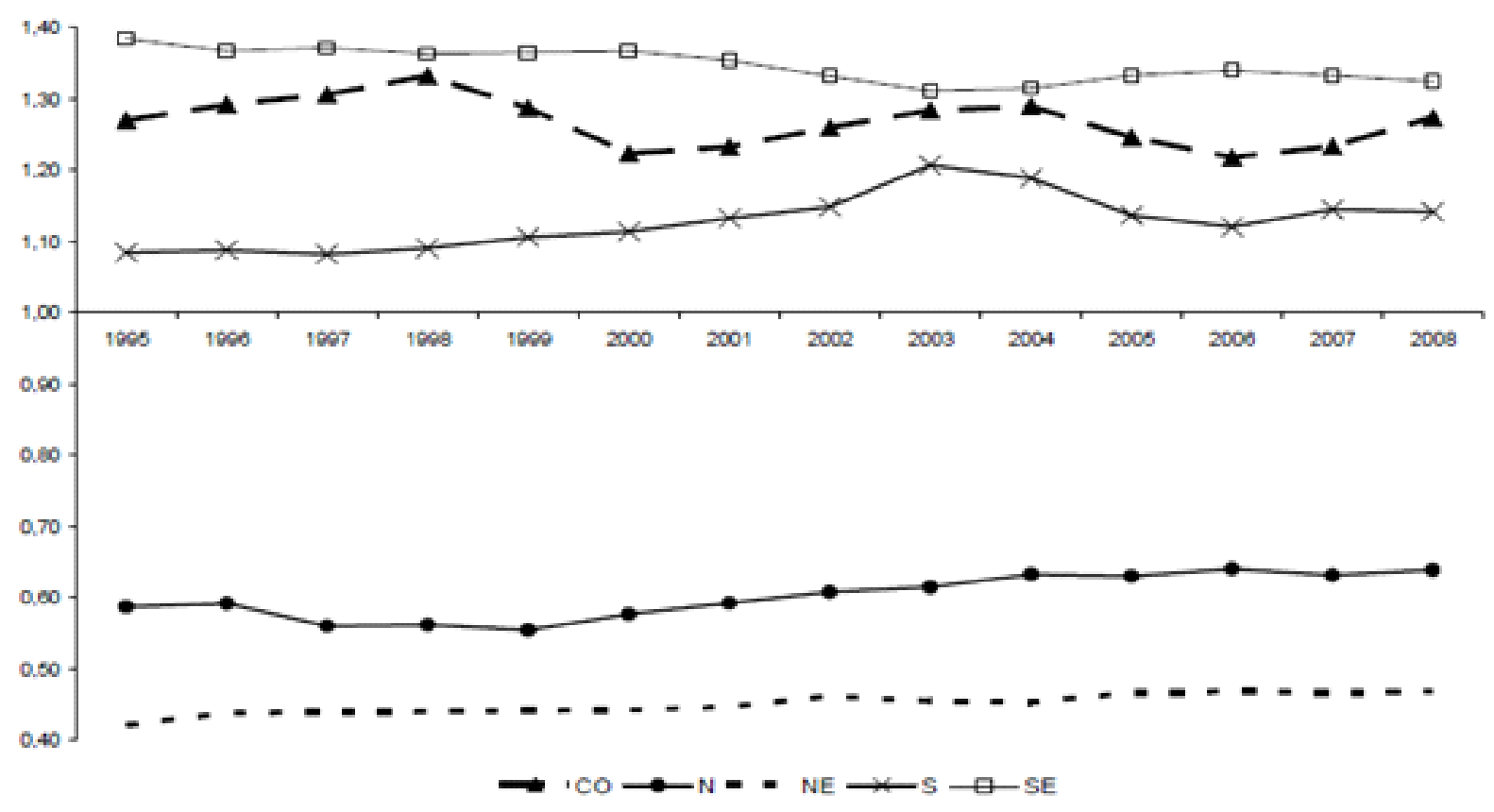

Fonte: Ipea a partir de dados do IBGE (2010)

Gráfico II - Razão entre o PIB per capita das macrorregiões e o PIB per capita brasileiro (1995-2008)

Pelo exposto, não parece caber dúvida de que as desigualdades regionais no Brasil são muito acentuadas e vêm de longa data, ou seja, são severas e igualmente persistentes no tempo.

Diante da situação acima esboçada, cabe trazer para reflexão a observação do prof. Michael Dunford, da Universidade de Sussex (GB), na Introdução de artigo de sua autoria, publicado em 2007, em que afirma:

A concentração das atividades econômicas e da população em uma parte relativamente pequena da superfície terrestre é uma constante por todo o planeta... [não sendo]... em grande medida, julgada problemática. Onde há mais desacordo é com relação à questão se é aceitável ou não que existam grandes e duradouras diferenças nos padrões de qualidade de vida entre e no interior das áreas em que pessoas vivem e trabalham. ("Desenvolvimento territorial, bem-estar e crescimento: razões em favor das políticas regionais" in Políticas de Desenvolvimento Regional: Desafios e Perspectivas", MI/IICA, Clélio Campolina Diniz, organizador; grifo nosso).

Quanto a ser, conforme citado anteriormente, "aceitável ou não que existam grandes e duradouras diferenças nos padrões de qua- lidade de vida entre e no interior das áreas em que pessoas vivem e trabalham" ou, em outras palavras, se o Estado deve ou não atribuir prioridade a políticas públicas incisivas direcionadas à desconcentração das atividades produtivas no território, muito provavelmente alude o professor Dunford ao debate que se arrasta há décadas entre economistas neoclássicos e economistas estruturalistas ou desenvolvimentistas. Estes propugnam por uma intervenção decidida do Governo, via planejamento e investimentos estruturais, de modo a alavancar o crescimento de espaços menos desenvolvidos, diminuindo-se assim a concentração de renda regional, enquanto neoclássicos advogam que, do ponto de vista econômico, não há razão para a preocupação com a concentração espacial dos investimentos produtivos, e com os consequentes diferenciais de renda per capita, pois tais fenômenos seriam "friccionais", isto é, se resolvem via migração. Ainda segundo essa corrente, do ponto de vista do crescimento econômico, a alocação ótima de recursos é atingida quando deixada à livre decisão dos agentes econômicos, daí por que a ação do Estado, no sentido de direcionar espacialmente os investimentos produtivos, será 
sempre ineficiente, ou seja, comprometerá de alguma forma a produtividade do sistema econômico, gerando-se resultados subótimos, em termos de produto total. Evidentemente que o professor Dunford se alinha à visão estruturalista-desenvolvimentista, bastando se verifique o título de seu artigo.

Paradoxalmente, no entanto, se nos voltamos para o exame da intervenção do Estado brasileiro na questão regional, a despeito das ainda graves disparidades do país, será possível constatar que o Estado teve uma posição pioneira na criação de instrumentos, ações e institucionalidades para alavancar o desenvolvimento do Nordeste e da Amazônia, que datam da época do Império.

Vamos examinar preliminarmente, de forma sucinta, as cinco etapas históricas da política regional brasileira ${ }^{3}$, de modo a abordar, em seguida, a etapa que se inicia, em fins de 2003, com o lançamento da Política Nacional de Desenvolvimento Regional:

\section{i Primeira etapa: 1877-1938}

Estima-se que, como consequência das secas no Nordeste e dos problemas sociais delas decorrentes, tenham morrido, na região, entre 100 e 200 mil pessoas, nas últimas décadas do século XIX. Calcula-se também que, entre o final do século XIX e início do século XX, aproximadamente 500 mil pessoas tenham se transferido ou foram transferidas daquela região para a região amazônica, na expectativa das oportunidades de trabalho vinculadas à exploração da borracha, que emergia como novo produto de exportação, impulsionada pela demanda da I Grande Guerra Mundial.

Dados os efeitos das secas no Nordeste e diante das pressões exercidas pelas elites da região, foi criada, em 1877, a Comissão Imperial, encarregada de analisar o problema e propor soluções. Aquela comissão sugeriu o desenvolvimento dos transportes, a construção de barragens e a transposição do rio São Francisco. As ações foram, no entanto,

\footnotetext{
${ }^{3}$ Esta parte deste texto relativo à história e periodização da intervenção do governo na questão regional é adaptação do documento de referência da Conferência Nacional de Desenvolvimento Regional e do relatório "Fundos Constitucionais de Financiamento", ambos disponíveis no site do MI.
}

limitadas e lentas. Em 1904, foram criadas comissões para analisar o problema das secas no Ceará e no Rio Grande do Norte e, no mesmo ano, criada a Inspetoria de Obras Contra as Secas (IOCS), transformada em Inspetoria Federal de Obras Contra as Secas (IFOCS), em 1906. Em 1920, foi criada a Caixa Especial de Obras de Irrigação de Terras Cultiváveis no Nordeste do Brasil, com $2 \%$ do orçamento da União. Em 1923, a Constituição Federal destinou $4 \%$ do orçamento federal para o controle das secas. No que se refere à Amazônia, diante da concorrência asiática, foi criada, em 1912, a Superintendência de Defesa da Borracha.

\section{ii Segunda etapa: 1939-1957}

Nesse período, não é possível identificar ainda uma política incisiva para a redução das desigualdades regionais, muito embora a Constituição de 1946 haja estipulado vinculações orçamentárias específicas para o desenvolvimento das regiões Nordeste e amazônica.

Em 1942, no bojo dos acordos de Washington, foi criado o Banco de Crédito da Borracha. Em 1945, seguindo a experiência do TVA (Tennessee Valley Authority), foi criada a Companhia Hidroelétrica do São Francisco e, em 1948, a Comissão de Desenvolvimento do Vale do São Francisco. A Superintendência de Defesa da Borracha foi transformada em Instituto Internacional da Hileia Amazônica, em 1945, e em Superintendência do Plano de Valorização Econômica da Amazônia, em 1953.

Importa ressaltar a criação do Banco do Nordeste do Brasil (BNB), em 1952, e a constituição pelo presidente Juscelino Kubitschek do Grupo de Trabalho para o Desenvolvimento do Nordeste (GTDN), em 1956, coordenado pelo economista Celso Furtado, do qual resultou um marco da política regional, que foi o seminal relatório "Uma Política de Desenvolvimento Econômico para o Nordeste".

A ação de Governo, no entanto, mais relevante do período foi a Marcha para o Oeste, lançada por Getúlio Vargas, ao final da década de 1940, com o objetivo de desconcentrar a população que à época se achava fortemente localizada na região litorânea, e induzir atividades econômicas nas regiões Centro-Oeste e Norte, então esparsamente povoadas. 


\section{iii Terceira etapa: 1958-1975}

A construção de Brasília, na segunda metade da década de 50, apesar de empreendida também com o objetivo de integração do território nacional, pode ser vista como o elemento de maior impacto na indução de um processo de desconcentração produtiva e populacional do território brasileiro do século passado, isto porque Brasília não apenas passou a funcionar como nódulo da integração de um sistema rodoviário composto por grandes troncos rodoviários (Brasília-Belém; BrasíliaBelo Horizonte; Brasília-São Paulo; BrasíliaCuiabá; Brasília-Barreiras, e suas ramificações), como induziu a ocupação do centro do país, região relativamente vazia até então, bem como permitiu a incorporação produtiva dos cerrados, viabilizando a expansão da extensa fronteira agrícola do Centro-Oeste brasileiro.

No período em análise, com o objetivo de impulsionar o desenvolvimento das regiões Norte e Nordeste, o Governo Federal lançou, a partir da década de 1960, um amplo conjunto de incentivos fiscais destinados a fortalecer a infraestrutura econômica e estimular o surgimento de uma classe empresarial regional. Para gerir aqueles instrumentos, um conjunto de instituições foi criado: a Superintendência do Desenvolvimento do Nordeste (SUDENE), em 1959, a Superintendência do Desenvolvimento da Amazônia (SUDAM), em 1966, e a Superintendência da Zona Franca de Manaus (SUFRAMA), em 1967. O Banco de Crédito da Borracha (1942) foi transformado em Banco de Crédito da Amazônia, em 1957, e em Banco da Amazônia, em 1966. Os incentivos instituídos na década de 60 , em que pesem às críticas que se faça à forma de concessão, uso inadequado, desvio de recursos e corrupção, tiveram importância decisiva na atração de um grande número de projetos para as regiões Norte e Nordeste, os quais se refletiram na expansão produtiva e na geração de renda e emprego.

Com base nas experiências de criação de instituições dedicadas ao desenvolvimento econômico do Norte e Nordeste, generalizouse, no período em análise, a adoção pelo Governo Federal da mesma abordagem para as demais regiões do País: Superintendência do Plano de Valorização Econômica da Região da Fronteira Sudoeste do País, em 1961, transformada em Superintendência do
Plano de Valorização Econômica da Região da Fronteira Sudoeste do País (Sudesul), em 1967; e a Comissão de Desenvolvimento do Centro-Oeste, em 1961, transformada em Superintendência de Desenvolvimento do Centro-Oeste (Sudeco), em 1967.

\section{iv Quarta etapa: 1976-1989}

Como se sabe, os anos 1980 entraram para a história recente do Brasil como "a década perdida", em virtude da crise econômica que se abateu no país a partir dos dois choques internacionais do petróleo (1973 e 1978). No período em referência, o Estado Desenvolvimentista entra em crise, prenunciando, de certa forma, as políticas neoliberais que se seguiriam na década de 1990. A brutal elevação internacional dos juros, que se agravou a partir de 1979, tornou a dívida externa impagável, desestruturando as finanças públicas e desencadeando uma forte aceleração inflacionária e estagnação. Seguiram-se políticas recessivas, arrochos salariais, desemprego e hiperinflação, que reduziram o poder de compra e contribuíram para acelerar o processo de concentração de renda pessoal e regional no país. Diante desse quadro, paulatinamente as instituições e instrumentos de política regional, criados na década anterior (1960), entram em decadência, passando a operar por inércia, subsistindo, ano após ano, com orçamentos cada vez mais minguados.

A única exceção positiva digna de nota naquele período foi a criação dos Fundos Constitucionais de Financiamento do Norte (FNO), Nordeste (FNE) e Centro-Oeste (FCO), estabelecidos pela Constituição Federal de 1988, que viriam a representar, nas duas próximas décadas, um importante aporte de recursos para os setor produtivo das três regiões.

\section{v Quinta etapa: 1990-2002}

Após o estapafúrdio governo Collor (1990-1992) e do estupor nacional que se seguiu à sua destituição, abriu-se, a partir de 1995, o período de ouro da era neoliberal, ao longo dos dois períodos de governo do Presidente Fernando Henrique Cardoso (FHC).

Já o governo Collor, em linha com os ditames do Consenso de Washington, Banco 
Mundial e FMI, dera início ao desmonte sistemático do aparato do Executivo federal, com a Medida Provisória $n^{\circ} 150$, de 15 de março de 1990, que previa uma alteração radical na estrutura organizacional do Executivo federal ${ }^{4}$. Foram extintos diversos ministérios, secretarias e órgãos especiais, inclusive a SUDECO, naquele mesmo ano.

Esse processo só se fez acentuar na era FHC, ainda sob a justificativa do controle da inflação e do ajuste fiscal, quando praticamente abandonou-se o campo das políticas públicas de planejamento e desenvolvimento regional, tendo sido o mercado elevado a fator chave orientador das decisões nacionais, inclusive de sua dinâmica regional. Nessa perspectiva, prosseguiu, naquele período, o esforço de desativação dos instrumentos de promoção do desenvolvimento regional, despontando como medidas emblemáticas a extinção da SUDENE e da SUDAM, em 2001.

De tal forma a "questão regional" tornou-se anátema na era FHC que não era possível identificar uma única rubrica no Orçamento Geral da União (OGU) onde uma ação voltada ao desenvolvimento regional pudesse ser inserida.

Por sua vez, os projetos prioritários de infraestrutura, no âmbito do programa dos "Eixos Nacionais de Integração e Desenvolvimento", iniciativa associada ao Plano Brasil em Ação (PPA 1996-1999), e à retomada no Plano Avança Brasil (PPA 20002003), expressavam uma opção prioritária pela integração dos espaços dinâmicos do Brasil ao mercado externo. O objetivo dos "eixos de desenvolvimento" era dotar de acessibilidade os "focos dinâmicos" do Brasil (agrícolas, agroindustriais, agropecuários ou industriais), negligenciando-se áreas menos dinâmicas.

A ideia original despontou em fins do primeiro governo $\mathrm{FHC}$, e se assentava em uma proposta de desenvolvimento ancorada nas ideias de logística, competitividade e redução do "custo Brasil". O estudo prévio à adoção da política dos "eixos" se tornou o principal insumo para a elaboração do PPA 2000-2003 (Plano Avança Brasil). A definição

\footnotetext{
${ }^{4}$ Ver "Reforma do Estado no Brasil (1995-1998): O Plano Diretor da Reforma do Aparelho do Estado Brasileiro", de Visentini, Georgine Simões, dissertação de mestrado, UFRS, 2006.
}

desse Plano privilegiou os fluxos reais de bens e serviços com destaque para as redes intermodais de transporte e logística. Solidária à visão liberal do processo de desenvolvimento econômico, o estudo posiciona o Estado brasileiro como indutor da realização de investimentos privados, tendo o planejamento um cunho meramente indicativo. A perspectiva de se avançar com investimentos em obras de infraestrutura, atrasadas face à restrição fiscal então vigente, gerou expectativas positivas dos entes federados e suas forças políticas. A estratégia dos "eixos" teve pelo menos o mérito de recolocar o debate sobre a espacialidade do desenvolvimento brasileiro.

Em verdade, a concepção subjacente à proposta dos "eixos" era a viabilização de formas mais eficientes para se acessar os "bolsões de riqueza" do território nacional. Evidentemente que este cenário tenderia, caso implantado, a potencializar as heterogeneidades estruturais entre e dentro das regiões brasileiras. O grau de efetiva implantação dos projetos contemplados pelos "eixos" foi, no entanto, baixo, não tendo atingido $20 \%$ de execução. A crença na força do investimento privado em infraestrutura mostrou-se - hélàs! - demasiado otimista.

O novo tipo de regionalismo praticado naquele período, intitulado por seus críticos de "provincianismo mundializado", foi denunciado à época por diferentes autores (Pacheco, Carlos Américo, 1998; Bacelar, Tânia, 1999), para quem as práticas realizadas no âmbito de espaços dinâmicos e competitivos, ao organizar sua articulação direta para fora do país, tendiam a romper os laços de solidariedade com o restante do território nacional, traduzindo-se efetivamente em políticas explícitas de segregação dos espaços não competitivos, às quais estaria associado o risco de "desintegração nacional".

Política regional se limitou, portanto, nas eras Collor e FHC, a ações difusas de desenvolvimento local com foco em "territóriosproblema", em linha, como mencionado, com as orientações dos organismos multilaterais de fomento ao desenvolvimento local/regional. Além de assumir escalas mínimas como preferenciais da política regional, privilegia-se a participação da comunidade local nas discussões em torno da concepção e implementação das novas políticas de de- 
senvolvimento regional, em contraposição ao tradicional modelo de intervenção centralizado do Estado brasileiro. As relações mercantis de exploração, as lutas de classes e os conflitos regionais passam a se subordinar ao consenso cívico local, e variáveis exógenas, como câmbio, juros, fisco, regulação trabalhista e fundos públicos, são olimpicamente ignoradas.

Concluo aqui o esforço de sintetizar as diferentes etapas da política regional brasileira até o lançamento da Política Nacional de Desenvolvimento Regional (PNDR). Pode-se deduzir, pelo exposto, que ao chegar ao poder, em 2003, a coalização de partidos de esquerda liderados pelo Presidente Lula encontra aos cacos as instituições e os instrumentos criados em décadas anteriores para a promoção do desenvolvimento regional.

Os tempos, porém, eram outros; não sendo mais possível cogitar-se da reprodução das condições em que políticas, instituições e instrumentos para o desenvolvimento regional haviam sido criados na década de 1960, pois o processo de globalização se intensificara, a democratização era uma realidade, a experiência do Estado desenvolvimentista era capítulo encerrado da história nacional, e o modelo neoliberal não se revelara o caminho redentor, como propalado no início da década de 1990, pois a taxa média de crescimento anual do PIB brasileiro, na década de 2000 $(2,6 \%)$, se bem conseguira superar a pífia taxa de 1,7\% da década anterior (1980), ainda deixava muito a desejar, comparativamente ao crescimento de 8,7\% da década de 1970.

Nesse contexto, o Presidente Lula anuncia, como um dos pontos centrais de Governo, enfrentar-se o fato de o Brasil ser uma das nações mais desiguais do mundo. Diante desse desafio, programas sociais seriam lançados com vistas a mitigar a grave situação social "das dezenas de milhões de homens, mulheres e crianças vivendo abaixo da linha de pobreza, submetidos a todas as formas de insegurança e violência".

Nessa perspectiva, a "questão regional" foi considerada peça central da estratégia no enfrentamento do desafio da diminuição das desigualdades do país, tendo esse compromisso sido expressamente ratificado no MEGAOBJETIVO II do PPA 2004/2007, que propõe, entre outros objetivos, "reduzir as desigualdades regionais e intrarregionais com integração das múltiplas escalas espaciais (nacional, macrorregional, sub-regional e local), estimulando a participação da sociedade no desenvolvimento local".

A primeira equipe que, à época, chegou ao MI para ocupar a antiga Secretaria de Políticas de Desenvolvimento Regional (SDR) foi a responsável pela elaboração da proposta da PNDR, lançada em fins de 2003. No texto do documento, é claramente visível a ruptura com o modelo neoliberal de desenvolvimento regional até então vigente, alinhando-se claramente a uma "visão furtadiana" de abordagem, pela qual o Governo federal é chamado a lançar programas regionais com recursos substantivos, viabilizando-se investimentos estruturantes, entendidos necessários à reversão da histórica defasagem entre as regiões desenvolvidas e não desenvolvidas do Brasil.

Além da expectativa de recursos adicionais, os pressupostos principais da proposta da PNDR foram assim apresentados:

1. As desigualdades regionais no Brasil do século XXI se manifestavam não apenas entre grandes regiões (Nordeste, Norte e Centro-Oeste x Sul e Sudeste), mas também no âmbito de cada região; daí a proposição de que a PNDR deveria atuar nacionalmente, em múltiplas escalas geográficas.

2. Era preciso recriar a estrutura institucional regional desmantelada na década de 1990 por governos anteriores (recriação das antigas Superintendências de Desenvolvimento do Nordeste, Norte e Centro-Oeste).

3. Dado que "desenvolvimento regional" é tema transversal, era necessário instituir instrumentos de governança que facilitassem a articulação da política regional que viria a ser conduzida pelo MI com a ação de órgãos setoriais federais, com o setor produtivo e a sociedade civil organizada.

Um traço inovador da PNDR está na "tipologia sub-regional" proposta, que seria utilizada na atribuição de prioridades e intervenções no território, muito à semelhança da abordagem adotada pela política regional europeia. A unidade geográfica de referência é a microrregional, segundo a classificação do IBGE. Duas variáveis foram utilizadas: o rendimento domiciliar médio, uma variável estática, de base decenal, e o crescimento do PIB per capita, uma variável dinâmica, ambas de fonte IBGE. Com o cruzamento das duas 
variáveis - rendimento domiciliar médio e crescimento do PIB per capita - decorreram quatro categorias de microrregiões, conforme representadas no Cartograma VII, abaixo.

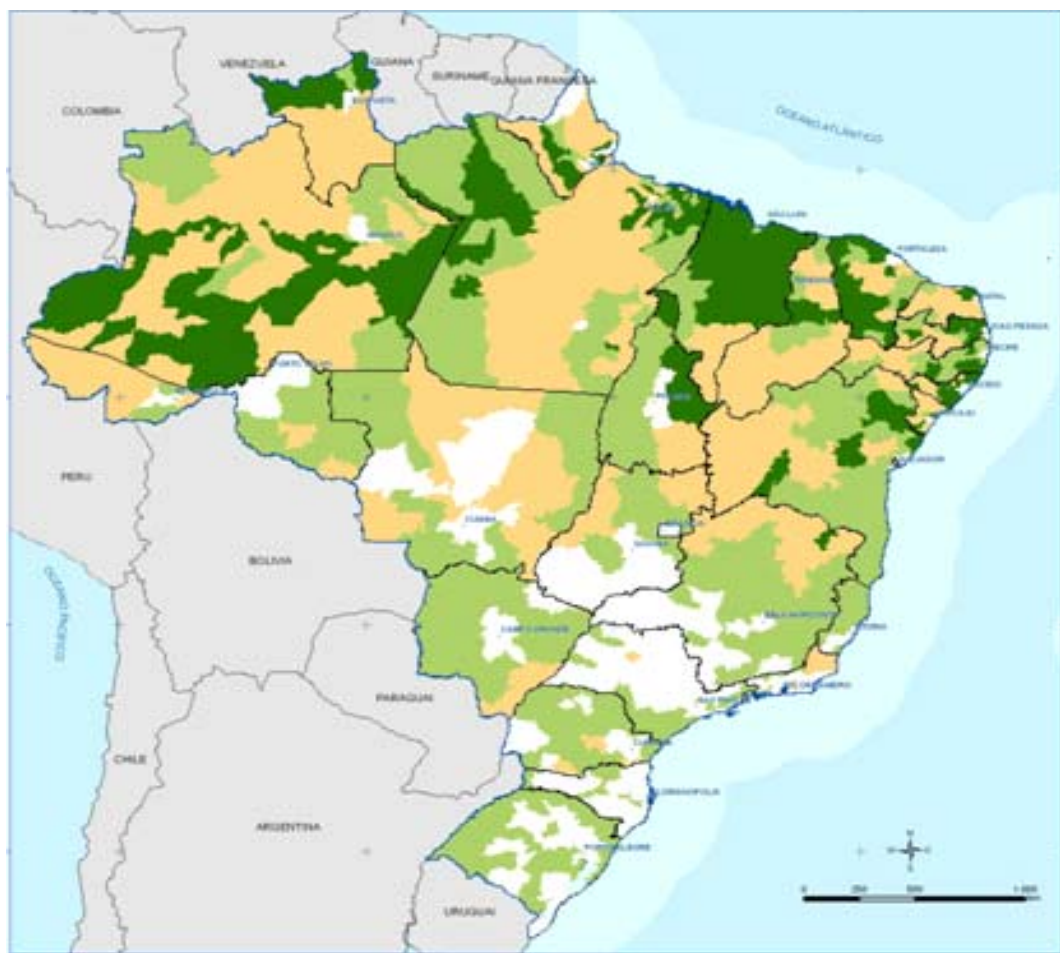

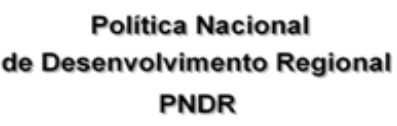

MAPA DA TIPOLOGIA

Tipologias sub-regionais
niveis de renda versus
niveis de variaçăo do
PIB 1991/2001

Legenda

Baixa Renda

Estagnadas

Dinâmicas

Alta Renda

Cartograma VII - Política Nacional de Desenvolvimento Regional (PNDR)

Com base na tipologia sub-regional da PNDR, foram definidas as seguintes áreas prioritárias indicadas no Cartograma:

1.Áreas em verde escuro - microrregiões de baixa renda e baixo dinamismo econômico. O grau de urbanização era o mais baixo $(50,4 \%)$, assim como o nível de educação (cerca de $60 \%$ da população com menos que 4 anos de estudo). Detinham participação de $1,7 \%$ no PIB, embora abrigassem $8,4 \%$ da população. O rendimento domiciliar médio era de apenas $27 \%$ da média nacional. Nessas áreas, a PNDR se propôs a atuar em sintonia com políticas sociais.

2.Áreas em verde claro - microrregiões de média renda e baixo dinamismo. Grau de urbanização relativamente elevado $(75,3 \%)$, e embora responsáveis por algo em torno de $18 \%$ do PIB nacional, concentravam cerca de $29 \%$ da população.

3.Áreas em amarelo ocre - microrregiões dinâmicas de menor renda. Regiões que passaram por transformações recentes na estrutura produtiva, em especial na agricultura. Grau de urbanização baixo $(57,9 \%)$, e embora abrigassem cerca de $9 \%$ da população nacional, respondiam por cerca de $4 \%$ do PIB.
As áreas brancas do Cartograma - de alta renda, independentemente de seu dinamismo - foram classificadas como áreas não prioritárias. Responsáveis por cerca de $76 \%$ do PIB nacional, detinham $53,7 \%$ da população. Foram consideradas "não prioritárias" no pressuposto de que disporiam de recursos suficientes para reverter as ocorrências de pobreza.

Além da tipologia, definida como "referencial" para a atuação em âmbito nacional, o texto original da PNDR declara, adicionalmente, que a atuação operacional do Ministério no território se daria na escala "mesorregional". Este provavelmente foi um recurso utilizado pelos formuladores da PNDR para preservar fontes orçamentárias herdadas do PPA 2000/2003, como o Programa de Mesorregiões Diferenciadas, o Programa Faixa de Fronteira e o Programa Semiárido do Nordeste.

Quanto ao arranjo institucional proposto no documento original da PNDR, com vistas ao estabelecimento de um modelo de governança que propiciasse a convergência da ação de Governo no território, o documento de 2003 define três níveis de coordenação e articulação das ações, nos níveis federal, macrorregional e sub-regional: 
1.No nível federal, criação da Câmara de Políticas de Integração Nacional e Desenvolvimento Regional e do Comitê de Articulação Federativa, sob coordenação da Casa Civil da Presidência da República.

2.No nível macrorregional - regiões Norte, Nordeste e Centro-Oeste - é feita referência à importância de elaboração de planos estratégicos de desenvolvimento, além da necessidade de recriação das Superintendências Regionais.

3.O nível sub-regional ficaria sob a responsabilidade dos fóruns e agências de desenvolvimento, que responderiam pela articulação e coordenação nas áreas de abrangência do Programa de Mesorregiões Diferenciadas.

Infelizmente, no entanto, as expectativas da equipe dirigente que chegara à SDR/ MI para formular e implementar a PNDR viriam a se frustrar logo em 2004. Como mencionado, uma aposta central da PNDR era a perspectiva de se contar com recursos adicionais para investimento nas áreas prioritárias ao desenvolvimento regional, a serem aportados através do Fundo Nacional de Desenvolvimento Regional (FNDR), cuja proposta fazia parte da PEC da Reforma Tributária, que tramitava, na ocasião, no Congresso Nacional com o objetivo de acabar com a guerra fiscal.

Apesar da intensa negociação do Executivo junto à bancada parlamentar dos Estados, a PEC da Reforma Tributária não chegou nem a ser submetida à votação do Congresso. Outra tentativa viria a ser conduzida pelo Ministério da Fazenda em 2008, com o mesmo resultado. A inviabilização do FNDR foi um duro golpe na premissa fundamental que norteara a formulação da estratégia da PNDR, pois ficou evidente que não seria possível contar-se com fonte de recursos para o financiamento de ações que não enquadravam nas linhas ofertadas pelos Fundos Constitucionais de Financiamento como, por exemplo, infraestrutura econômica, promoção da inovação, capacitação de recursos humanos, assistência técnica e outras, entendidas como necessárias à transformação das dinâmicas regionais.

Com a inviabilização do FNDR, se esvaneceu também, por consequência, a premissa básica da PNDR de atuar nacionalmente, em microrregiões prioritárias, com base na tipologia sub-regional estabelecida. Diante do impasse, a gestão do MI tendeu a voltar-se prioritariamente, desde 2004, para investimentos setoriais, como o Projeto de Integração do Rio São Francisco (PISF) e a Ferrovia Transnordestina, paralelamente que buscava fortalecer orçamentariamente ações herdadas do PPA anterior (2000/2003), como os programas mesorregionais, anteriormente mencionados.

Esse esforço de fortalecimento foi conduzido através da Câmara de Políticas de Integração Nacional e Desenvolvimento Regional, chefiada pela Casa Civil, criada logo após o lançamento da PNDR com o objetivo de articular e coordenar a ação de outros Ministérios e agências governamentais no território.

O MI, que detinha a Secretaria Executiva daquela Câmara, passou, desde 2004, a buscar a articulação da ação do Governo federal nas áreas correspondentes aos programas orçamentários de base territorial de sua competência, não apenas no sentido de identificar ações que outros Ministérios e agências ordinariamente executavam a partir de sua ação programática, mas também a pleitear um direcionamento preferencial de recursos orçamentários de fonte setorial (educação, saúde, transportes, energia, etc...) para áreas abrangidas pelo Programa de Mesorregiões Diferenciadas. Essa política não gerou resultados significativos, dadas às clássicas dificuldades do planejamento e coordenação intersetorial que subsistem, há décadas, na estrutura do Executivo brasileiro.

Do ponto de vista da gestão dos programas mesorregionais a cargo do $\mathrm{MI}$, independentemente da escassez de recursos orçamentários, a ação do MI ficou muito centrada na organização de arranjos produtivos locais (APLs), não tendo havido um apoio consistente de capacitação institucional dos fóruns e agências de desenvolvimento sub-regionais para que pudessem assumir as funções de articulação e coordenação que lhes havia sido atribuída.

Além de orçamentariamente pouco expressivos, os programas mesorregionais - PROMESO, CONVIVER e PDFF - a cargo da antiga Secretaria de Programas Regionais (SPR) do MI passaram a ser inflados por emendas, muito pouco focadas no desenvolvimento dos territórios que lhes eram objeto. $\mathrm{O}$ problema das emendas foi, inclusive, um dos 
pontos tratados na auditoria do TCU sobre a PNDR (Acórdão 2919/ 2009 - Plenário).

Ainda quanto à Câmara de Políticas de Integração Nacional e Desenvolvimento Regional, esta se reuniu algumas vezes, de 2003 a 2006; entretanto, a partir deste ano, entra em inatividade, não sendo mais convocada ao longo de todo o $2^{\circ}$ mandato do Governo Lula.

Quanto aos demais instrumentos da PNDR, criados para lhe assegurar condições mínimas de governança, os resultados foram os seguintes:

- O Comitê de Articulação Federativa, segunda instância de governança no nível federal da PNDR, jamais foi instalado.

- As Superintendências do Norte - SUDAM - e do Nordeste - SUDENE - foram recriadas proforma, em 2007, e a do CentroOeste - SUDECO - em 2011, não lhes tendo sido dadas, no entanto, até o presente, as condições operacionais mínimas para atuar adequadamente.

- Os Planos Estratégicos de Desenvolvimento do Nordeste, Norte e Centro-Oeste, que deveriam orientar as estratégias e ações de desenvolvimento e a promoção de iniciativas em territórios priorizados naquelas regiões, foram elaborados com o apoio da SDR/MI, mas nenhuma ação concreta derivou desses documentos, sobretudo por conta da fragilidade das Superintendências em lhes dar cumprimento, não tendo nem sequer sido aprovados como Lei, conforme previsto nas Leis de recriação das Superintendências.

Se, ao final do $1^{\circ}$ Governo Lula, a execução da PNDR ia de mal a pior, o coup de grâce viria em fevereiro de 2008, com o lançamento do Programa Territórios da Cidadania. Este programa, coordenado pela Casa Civil com base na experiência do Programa de Apoio ao Desenvolvimento Sustentável de Territórios Rurais (PRONAT), do Ministério do Desenvolvimento Agrário (MDA), estimava, apenas em 2008, assegurar investimentos de $\mathrm{R} \$ 11,3$ bilhões, provenientes de diversas fontes, a serem aplicados em 60 territórios (ampliados para 120, em 2009), compreendendo 958 municípios nas 27 unidades da Federação. Para sua execução, o MDA montou uma estrutura institucional transversal e integrada, muito próxima, aliás, daquela concebida pela PNDR, composta, no nível federal, de um Comitê Gestor Nacional (integrado por 22 Ministérios) e um Comitê Técnico; Comitês de Articulação Estaduais e Colegiados Territoriais.

Não é preciso dizer que o Decreto de lançamento daquele Programa foi entendido pelo MI, e em especial pela SPR, como um golpe branco, pois o MDA, apoiado pela Casa Civil, que assumiu a coordenação do Programa, passava a concorrer privilegiadamente com a SPR/MI na maioria das áreas de sua atuação, como mostram os Cartogramas VIII e IX abaixo.

$\mathrm{O}$ choque de realidade advindo do lançamento do Programa Territórios da Cidadania foi particularmente surpreendente porque, no ano anterior, em fevereiro de 2007, o presidente Lula assinara, em cerimônia no Palácio do Planalto, o Decreto $N^{\circ}$ 6.047, que instituiu a PNDR como política de Governo. A assinatura desse Decreto foi celebrada pelo MI como o sinal de retorno da PNDR à agenda do Governo, inclusive no sentido da adoção da tipologia sub-regional como referência para a atuação de agências governamentais setoriais no território. Esta tão desejada convergência de fato não ocorreu, à exceção dos agentes financeiros operadores dos Fundos Constitucionais de Financiamento (Banco do Brasil/ Centro-Oeste, Banco do Nordeste e Banco da Amazônia), que passaram a adotar as áreas prioritárias indicadas na tipologia microrregiões de baixa renda, estagnadas e dinâmicas - como referência para aplicações em suas respectivas regiões de atuação. 


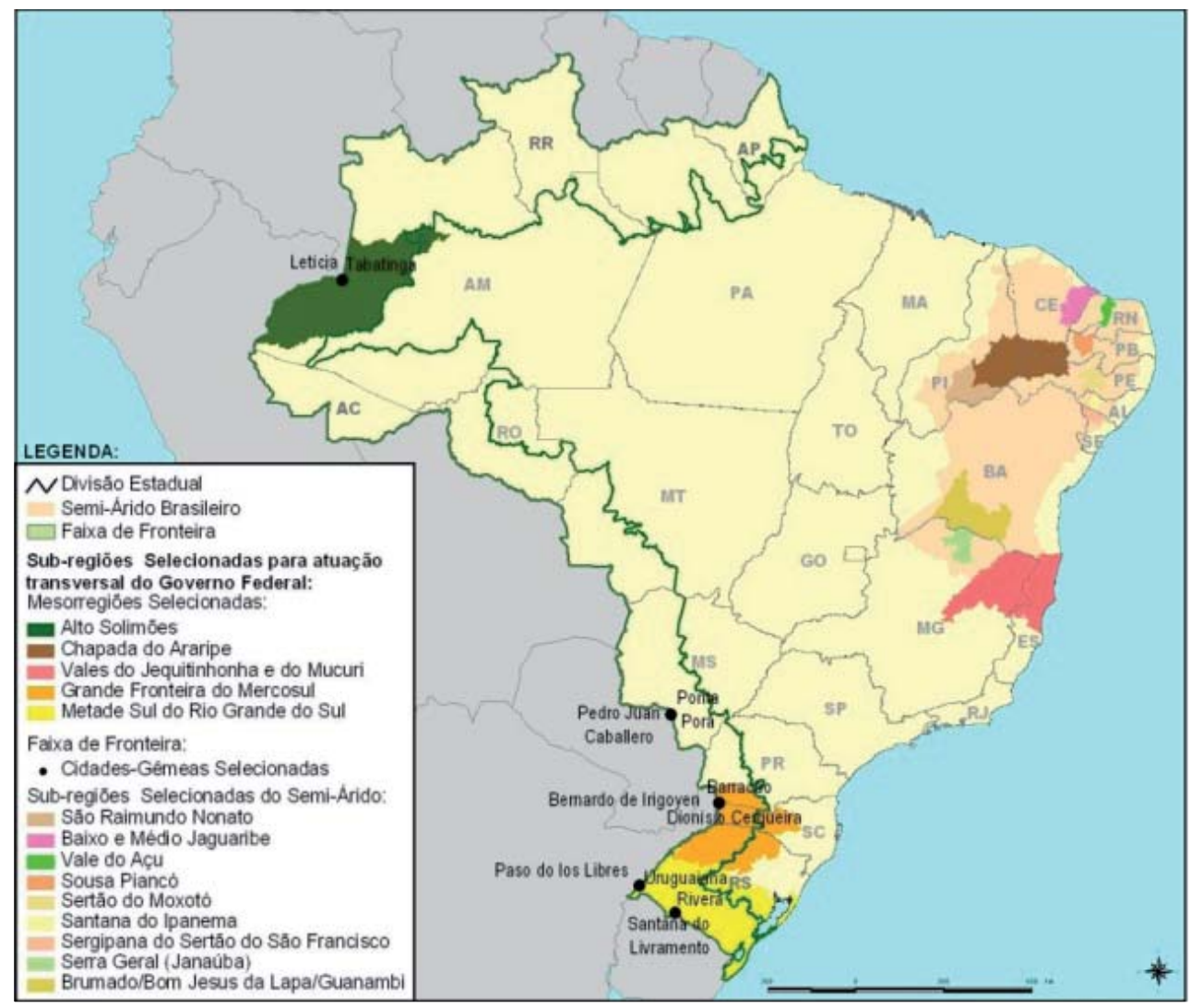

Cartograma VIII - Programas Mesorregionais do MI (2007)

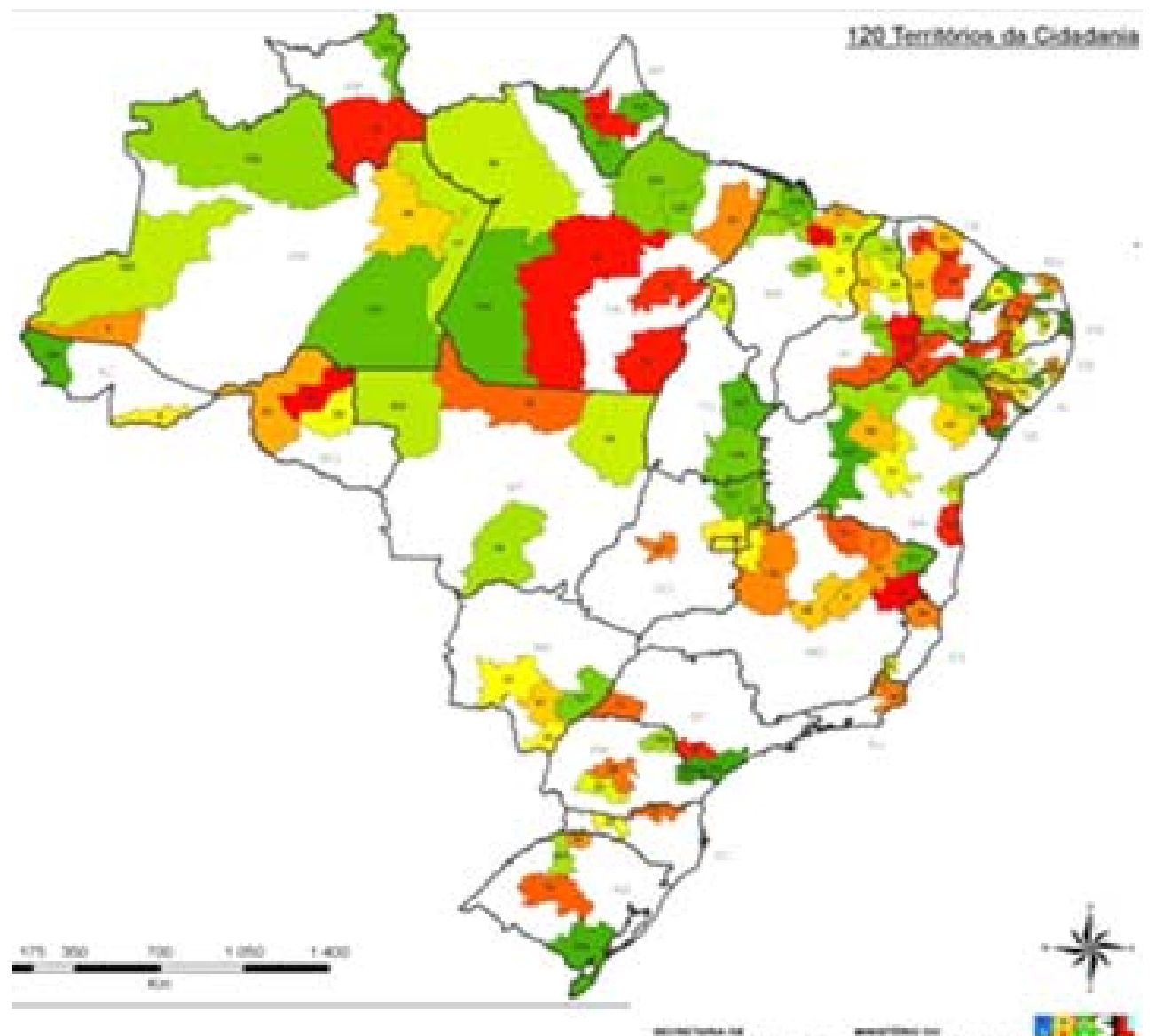

Cartograma IX - Territórios da Cidadania (2010) 
Ao que tudo indica, a opção pelo lançamento Programa Territórios da Cidadania, cujas ações são essencialmente de natureza social, em detrimento da ação regional desenvolvida pela PNDR, deveu-se, em primeiro lugar, à tendência geral do Governo Lula de privilegiar o combate à pobreza, paralelamente à execução de programas de infraestrutura do PAC.

Note-se que a opção daquele Programa foi justamente "combater a pobreza e as desigualdades sociais nas áreas rurais com baixos Indices de Desenvolvimento Humano (IDH) e de Educação Básica (Ideb)". Em segundo lugar, de acordo com seus formuladores, o mo- delo de governança adotado pelo Programa daria mais visibilidade pública nos territórios e um maior grau de conexão com a base de lideranças locais, comparativamente à PNDR, conferindo-lhe assim uma vantagem relativa, em especial política (ver, a esse respeito, o relatório "Avaliação da Política Nacional de Desenvolvimento Regional") ${ }^{5}$.

Os efeitos práticos da criação do Programa Territórios da Cidadania não se fizeram tardar. Observem, no Gráfico abaixo, a queda dos recursos orçamentários dos programas de base mesorregional do MI, desde o início do $2^{\circ}$ Governo Lula, em especial a partir do lançamento daquele Programa.

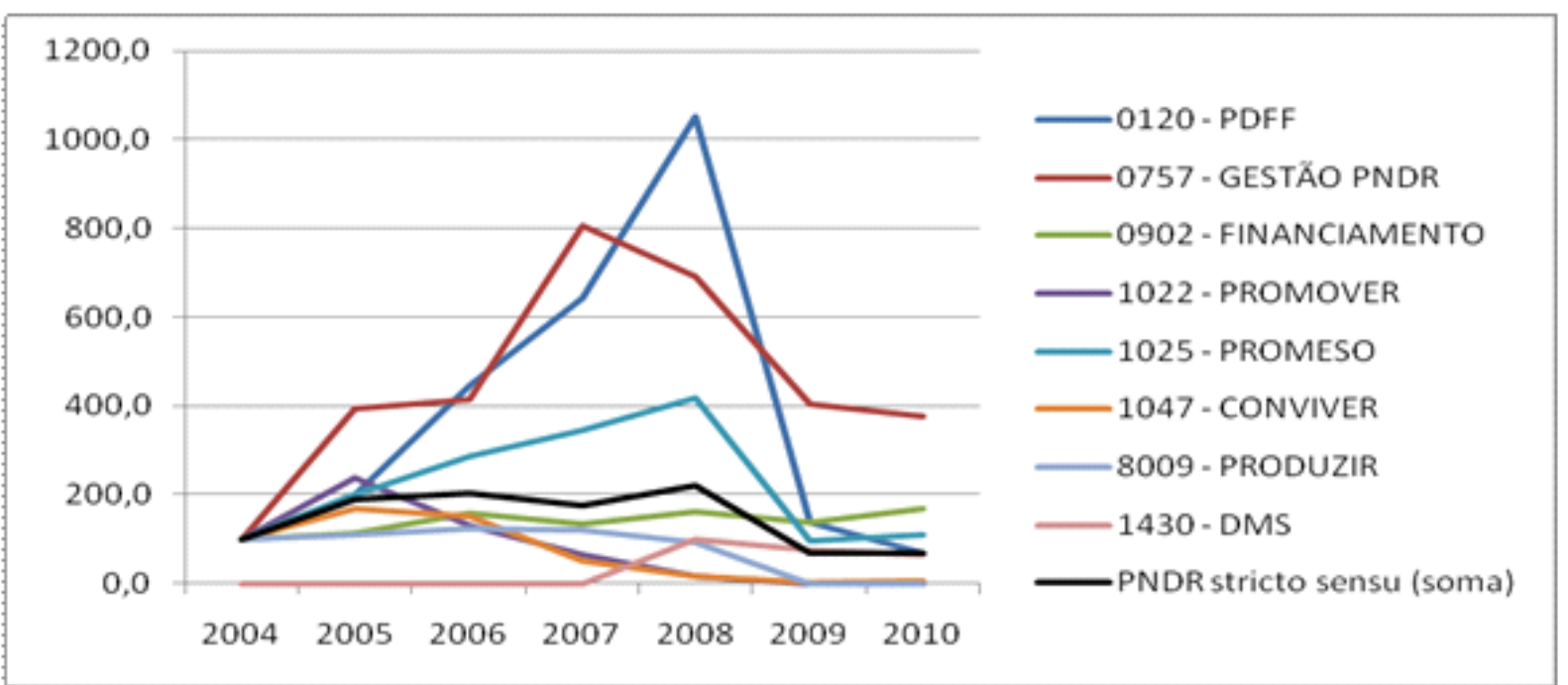

Gráfico III - Índice de evolução dos gastos dos programas da PNDR inscritos nos PPA 20042007 e 2008-2011

Fonte: Avaliação da Política Nacional de Desenvolvimento Regional.

Diante do evidente desmonte por que passava a PNDR, a antiga Secretaria de Políticas de Desenvolvimento Regional, sob cuja atribuição estava a execução da Política, promoveu, entre 2009 e 2010, um processo de reflexão e revisão do texto de 2003, de modo a legar à nova equipe que tomasse posse após a eleição presidencial de outubro de 2010, um documento propositivo com alternativas para a retomada das ações voltadas à diminuição das desigualdades regionais no país. Esse documento - "A PNDR em dois tempos: a experiência apreendida e o olhar pós-2010" - foi divulgado internamente ao MI em setembro de 2010, e se posicionava no sentido da retomada da política regional brasileira através de três linhas:
4.Transformação da PNDR de política de Governo a política de Estado, mediante o envio de Projeto de Lei ao Congresso Nacional.

5.Estabelecimento de um correspondente modelo de governança, que assegurasse a articulação, coordenação e integração de ações federais no território.

6.Criação do Fundo Nacional de Desenvolvimento Regional (FNDR), entendido como imprescindível na estratégia de redução das desigualdades regionais.

A nova equipe dirigente que assume o MI no início de 2011 se posicionou oficialmente a favor de relançar a PNDR. Foram

\footnotetext{
${ }^{5}$ Disponível em: <http://www.iica.int/Esp/regiones/ sur/brasil/Lists/Publicacoes/DispForm.aspx?ID=138>.
} 
retomadas as negociações junto à Casa Civil e ao Ministério do Planejamento com vistas à convocação da Câmara de Políticas de Integração Nacional e Desenvolvimento Regional, e uma nova proposta de Política (PNDR II) passou a ser gestada no âmbito da nova Secretaria de Desenvolvimento Regional.

Além de reafirmar a necessidade de colocar a questão das desigualdades regionais como prioridade na agenda política nacional, mediante a transformação da PNDR em política de Estado, e da implantação de um Sistema Nacional de Desenvolvimento Regional, que ensejasse a coordenação vertical e horizontal da ação pública no território, viabilizando-se assim uma ação efetiva em múltiplas escalas, a nova SDR apontou "fatores estruturais de atraso" - estrutura produtiva, rede urbana, infraestrutura, ciência e tecnologia e qualificação de recursos humanos - como focos prioritários das ações da PNDR, em sua fase II.

Diante das incertezas relativas à perspectiva de encaminhamento ao Congresso de uma nova proposta de reforma tributária no bojo da qual se inserisse o FNDR, a SDR, cautelosamente, optou, sem abdicar de gestões com vistas à criação desse fundo, por sugerir outras fontes de financiamento para a Política, como, entre outras: a incorporação de parte dos ganhos decorrentes da renegociação dos parâmetros aplicados ao pagamento das dívidas estaduais; a vinculação de parte dos royalties do petróleo a ser entregue a estados e municípios para investimentos em infraestrutura; e a incorporação de parte das receitas da CIDE (Contribuições de Intervenção no Domínio Econômico) incidente na importação de petróleo.

Uma iniciativa ousada lançada no início de 2012 se concretizou na $1^{\circ}$ Conferência Nacional de Desenvolvimento Regional (CNDR). Ao propor a realização de uma ampla "conferência nacional", por meio da qual resultassem princípios e diretrizes em apoio à formulação da PNDR II, o MI alinhou-se à abordagem adotada pela Casa Civil, desde o $1^{\circ}$ Governo Lula, com o objetivo de agregar participação social à formulação de políticas públicas, como tinham sido os casos das Conferências Nacionais de Saúde, Cidades, Segurança Pública, entre outras.

A CNDR foi, sem dúvida, um grande esforço político, organizacional e financeiro empreendido pelo MI, por sua SDR, com vistas a legitimar a PNDR II por intermédio da concertação federativa e social. Foi elaborado um documento de referência ${ }^{6}$ em orientação às discussões e deliberações que teriam lugar ao longo do processo conferencial. Um amplo debate de âmbito nacional foi instaurado, com a realização de 27 etapas estaduais e 5 etapas macrorregionais, que reuniram cerca de 10.000 participantes de sociedade civil, empresariado, setor público e instituições de ensino superior, pesquisa e extensão. A plenária nacional, ocorrida em março de 2013, em Brasília, teve a participação de 354 delegados e cerca de 2.400 participantes, tendo sido aprovados 21 Princípios e 95 Diretrizes.

Com base nos resultados da Conferência, a SDR passou então a centrar esforços em duas frentes: na preparação da proposta oficial da PNDR II, que deveria ser transformada, até setembro de 2013, em projeto de lei para encaminhamento ao Congresso Nacional, e em rodadas de negociação com Ministérios, instituições de governo e agências de fomento, com vistas a consolidar um Pacto de Metas, pelo qual se assegurasse a convergência da ação de Governo em torno de carteiras de projetos em "regiões programa" (regiões prioritárias), a serem definidas com base na tipologia sub-regional da nova Política.

Partindo da constatação do "déficit de coordenação" entre as instituições governamentais setoriais (PAC, PNLT, PNS, PNE, entre outras) e de base territorial (Comitês de Bacia, Territórios da Cidadania, Política de Apoio a APLs, entre outras), o Pacto de Metas se propunha a estabelecer, através de sucessivas reuniões de pactuação com a direção superior daquelas instituições, um conjunto de "agendas de convergência" que conciliassem as metas dos agentes setoriais, conforme seus planos e programas inscritos no PPA 2011/2014, e as áreas geográficas (regiões programa) de interesse da PNDR II, assegurando-se assim a tão desejada convergência da ação pública no território. Esse mesmo exercício deveria ser reproduzido, em uma segunda etapa, junto aos Estados.

\footnotetext{
${ }^{6}$ Disponível em: <http://www.mi.gov.br/c/ document_library /get_file?uuid=54bce099-503a-40768613-d90dd6107c79\&groupId=10157> .
} 
Infelizmente, no entanto, mais uma vez a realpolitik conjurou contra as pretensões da PNDR. Mudanças ministeriais ocorridas ao longo do primeiro semestre de 2013 e boatos sobre a saída do PSB da base de apoio do Governo, que ganharam força a partir de meados do ano, prejudicaram bastante a continuidade das negociações previstas para montagem do Pacto de Metas. No início de outubro, o Ministro do MI e seu Secretário Executivo deixaram o Ministério, seguindo no mesmo rumo, algumas semanas depois, o Secretário da SDR, entrando, em consequência, a PNDR mais uma vez em compasso de espera ${ }^{7}$.

Se daqui a uns dez ou quinze anos, algum pesquisador se der ao trabalho de revisar a evolução das políticas e institucionalidades regionais no Brasil, provavelmente definirá o atual período, iniciado em 2003, como aquele em que prevaleceram as chamadas "políticas implícitas" 8 de desenvolvimento regional, como assim bem definiu a professora Tânia Bacelar, ou seja, um período em que os avanços na desconcentração regional da renda terá sido subproduto eventual de políticas macroeconômicas, como o aumento do salário mínimo real; de políticas setoriais, como as grandes obras de infraestrutura do PAC no Nordeste; e de políticas sociais, como os programas de transferência de renda a cargo do MDS. O MI e a PNDR (oficialmente a "política explícita" federal destinada a combater diretamente as desigualdades socioeconômicas regionais) ficaram totalmente à margem daquele processo, como destacado nesse breve relato.

É isto que pude trazer às senhoras e senhores no espaço que me foi disponibilizado. Agradeço a atenção de todos os presentes, e me coloco à disposição para receber, agora ou posteriormente, dúvidas ou contribuições sobre o tema aqui tratado.

\footnotetext{
${ }^{7}$ Este artigo foi concluído em fins de novembro de 2013, quando o Secretário Sérgio Castro já havia sido exonerado da SDR/MI, enquanto a apresentação no I Seminário Internacional sobre Desenvolvimento Territorial Sustentável ocorreu em 27 de agosto do mesmo ano.

${ }^{8}$ Conforme: <http://www.unisc.br/portal/upload/ com_arquivo/1378906922.pdf $>$.
} 